\title{
Determination of the Oxidation State of Irradiated Nuclear Fuel Using SIMS
}

\author{
C.T. Walker, S. Bremier, F. Belloni, D. Manara, R. Hasnoui and M. Ernstberger
}

European Commission, Joint Research Centre, Institute for Transuranium Elements, P.O. Box 2340, D-76125 Karlsruhe, Germany

During the fission of $\mathrm{UO}_{2}$ nuclear fuel oxygen is set free. Part of the oxygen liberated reacts with the fission products and forms oxides of these elements. The balance dissolves in the fuel matrix increasing its stoichiometry as indicated by the oxygen to metal $(\mathrm{O} / \mathrm{M})$ ratio, or is absorbed by the Zircaloy tube which contains the fuel. The O/M ratio is generally acknowledged to be the most important chemical property of $\mathrm{UO}_{2}$ nuclear fuel during irradiation. This is because the oxygen potential, $\Delta \bar{G}\left(\mathrm{O}_{2}\right)$, and the related $\mathrm{O} / \mathrm{M}$ ratio of the fuel, affect diffusion controlled processes such as grain growth [1], creep [2] and fission gas release [1], the thermal conductivity of the fuel [3] and the chemical state and hence the behaviour of the fission products. The $\Delta \bar{G}\left(\mathrm{O}_{2}\right)$ and O/M ratio of the fuel are not constant during irradiation but change with burn-up (time) due to the incorporation of fission products.

The $\Delta \bar{G}\left(\mathrm{O}_{2}\right)$ of irradiated $\mathrm{UO}_{2}$ nuclear fuel can be measured using a miniature solid-state galvanic cell (see e.g., ref. [4]). The method has a number of drawbacks. First, it is time consuming and labour intensive. Second, samples 0.5 to $1 \mathrm{~mm}$ in size are employed and consequently the number of radial positions that can be measured on a given fuel pellet is limited. Third, since the samples are obtained by coring or by breaking a thin disc cut from the fuel, their exact radial locations are often not known with certainty. Last, and most importantly, for irradiated $\mathrm{UO}_{2}$ nuclear fuel the conversion of $\Delta \bar{G}\left(\mathrm{O}_{2}\right)$ to $\mathrm{O} / \mathrm{M}$ ratio is associated with large uncertainties. This is because allowances have to be made for the effect of dissolved fission products of different valence and plutonium in the $\mathrm{UO}_{2}$ lattice, which involves many assumptions.

Recent work at ITU has revealed that it might be possible to measure the radial variation of the O/M ratio in irradiated $\mathrm{UO}_{2}$ nuclear fuel using secondary ion mass spectrometry (SIMS). Radial distributions of the ${ }^{16} \mathrm{O}^{-}$ion intensity, and the ${ }^{238} \mathrm{UO}_{2}^{+} /{ }^{238} \mathrm{U}^{+}$and ${ }^{238} \mathrm{UO}^{+} /{ }^{238} \mathrm{U}^{+}$ion intensity ratios were measured in a $\mathrm{UO}_{2}$ fuel with a pellet burn-up of $65 \mathrm{MWd} / \mathrm{kgHM}$ using ${ }^{133} \mathrm{Cs}^{+}$and $\left({ }^{16} \mathrm{O}\right)_{2}^{+}$ primary ion beams (see Figs.1 and 2). It is assumed that the form of the profiles accurately reflects the radial change in the fuel O/M. Accordingly, they reveal that although no change in the $\mathrm{UO}_{2}$ stoichiometry occurred in the interior of the fuel, the $\mathrm{O} / \mathrm{M}$ ratio increased close to the fuel surface before falling noticeably at the periphery. This latter observation is consistent with the view that the Zircaloy cladding acts as an oxygen getter.

To confirm that the ${ }^{16} \mathrm{O}^{-}$ion intensity profile and the ${ }^{238} U \mathrm{O}_{2}^{+} /{ }^{238} U^{+}$and ${ }^{238} U \mathrm{O}^{+} / /^{238} U^{+}$profiles represent the radial variation in the fuel stoichiometry, ion emission from three samples of unirradiated polycrystalline $\mathrm{UO}_{2}$ with stoichiometries of 1.96, 2.01 and 2.15 was studied. It was found that the ${ }^{16} \mathrm{O}^{-}$ion intensity correlates perfectly with the $\mathrm{UO}_{2}$ stoichiometry (Fig.3) and that a close relationship exists between the ${ }^{238} \mathrm{UO}_{2}^{+} /{ }^{238} \mathrm{U}^{+}$and ${ }^{238} \mathrm{UO}^{+} /{ }^{238} \mathrm{U}^{+}$ion intensity ratios and the $\mathrm{UO}_{2}$ stoichiometry (Fig. 4). Thus, it is concluded that SIMS can be used to measure the radial variation 
of the $\mathrm{O} / \mathrm{M}$ ratio in irradiated $\mathrm{UO}_{2}$ fuel. At present, it does not appear that the ${ }^{16} \mathrm{O}^{-}$ion intensity and ${ }^{238} \mathrm{UO}_{2}^{+} /{ }^{238} \mathrm{U}^{+}$and ${ }^{238} \mathrm{UO}^{+} /{ }^{238} \mathrm{U}^{+}$ion intensity ratios measured on unirradiated $\mathrm{UO}_{2}$ can be applied in a quantitative manner to determine the local stoichiometry of irradiated fuel. The values obtained on irradiated $\mathrm{UO}_{2}$ fuel are inconsistent with those for unirradiated $\mathrm{UO}_{2}$. It is assumed that this is mainly because for irradiated fuel the sputtering yield and the ${ }^{16} \mathrm{O}^{-},{ }^{238} \mathrm{UO}_{2}^{+},{ }^{238} \mathrm{UO}^{+}$and ${ }^{238} \mathrm{U}^{+}$ion yields are affected by the presence of fission products and transuranic elements dissolved in the fuel matrix and by radiation damage.

\section{References}

[1] M.A. Mansouri, D.R. Olander, J. Nucl. Mater. 254 (1998) 22.

[2] M.S. Seltzer et al., Review of out-of pile and in-pile creep of ceramic nuclear fuels, USAWC Report BMI-1906, 1971.

[3] P.G. Lucuta et al., J. Nucl. Mater. 223 (1995) 51.

[4] C.T. Walker et al., J. Nucl. Mater. 345 (2005) 192.

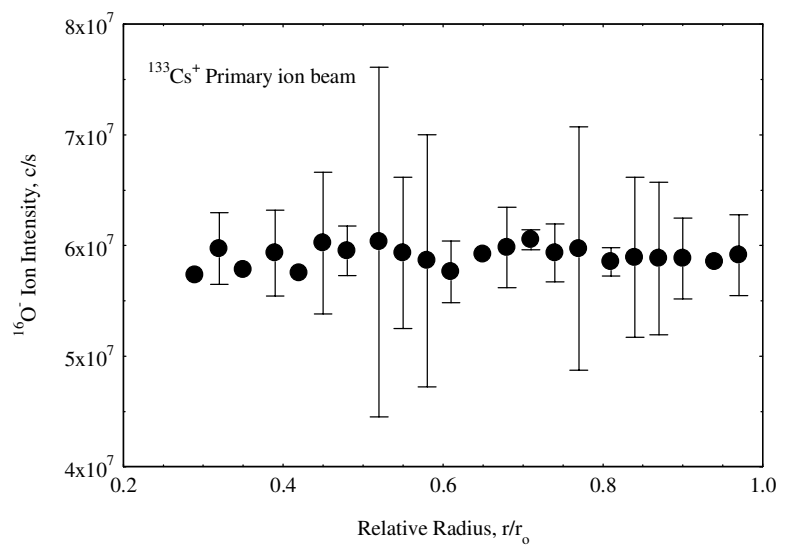

Fig.1. Distribution of ${ }^{16} \mathrm{O}^{-}$ion intensity across the radius of an irradiated $\mathrm{UO}_{2}$ nuclear fuel with a burn-up of $65 \mathrm{MWd} / \mathrm{kgHM}$.

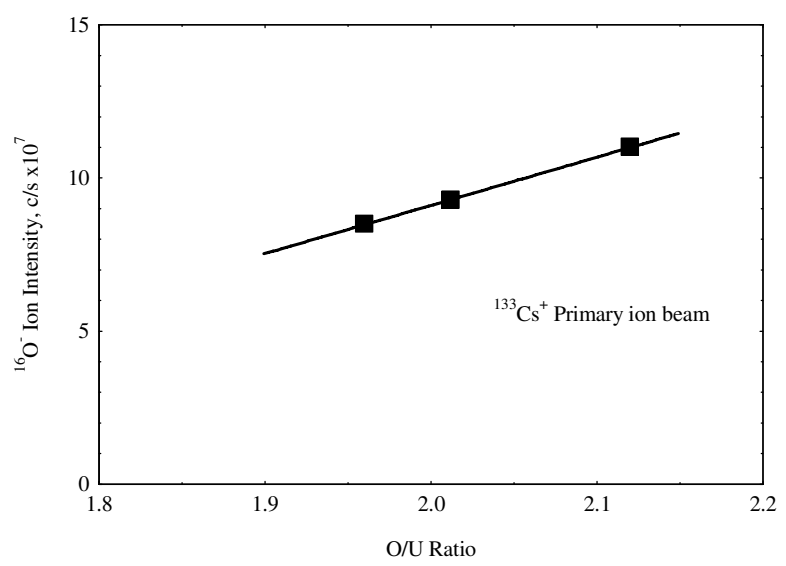

Fig.3. ${ }^{16} \mathrm{O}^{-}$ion intensity related to the stoichiometry of un-irradiated polycystalline $\mathrm{UO}_{2}$.

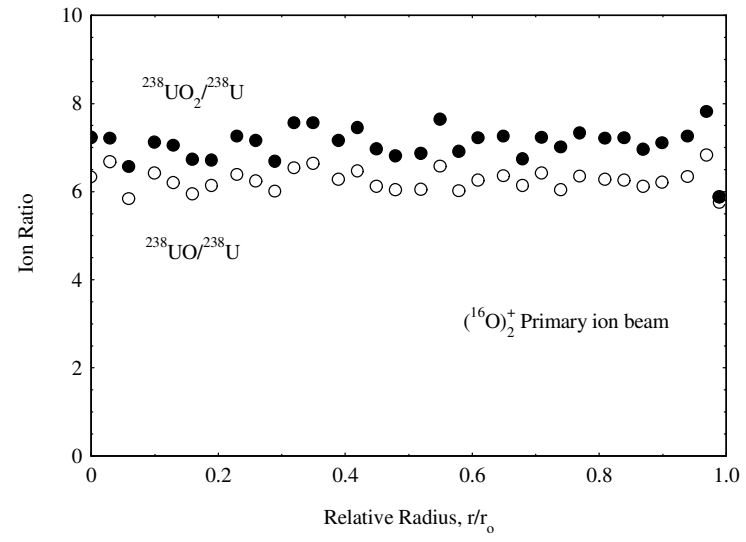

Fig.2. Variation of the ion ratios ${ }^{238} \mathrm{UO}_{2}{ }^{+} /{ }^{238} \mathrm{U}^{+}$and ${ }^{238} \mathrm{UO}^{+} /{ }^{238} \mathrm{U}^{+}$across the radius of an irradiated $\mathrm{UO}_{2}$ nuclear fuel with a burn-up of $65 \mathrm{MWd} / \mathrm{kgHM}$.

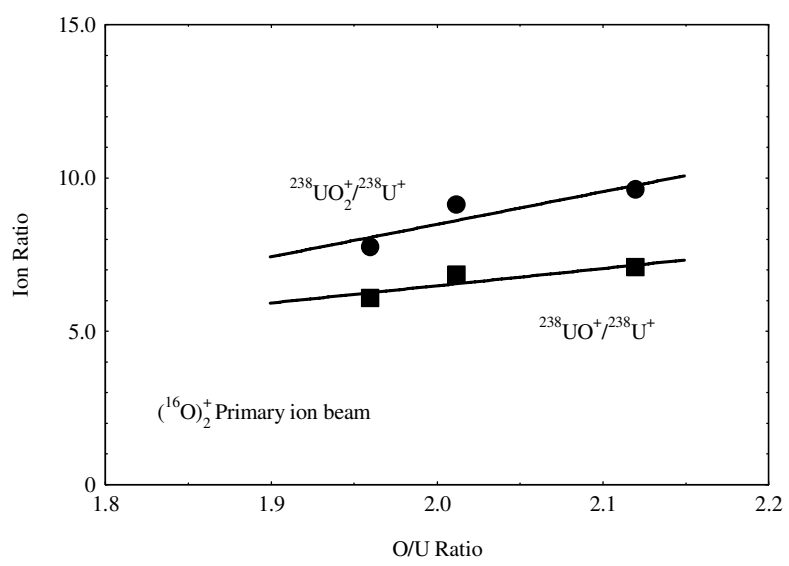

Fig.4. ${ }^{238} \mathrm{UO}_{2}{ }^{+}{ }^{238} \mathrm{U}^{+}$and ${ }^{238} \mathrm{UO}^{+} /{ }^{238} \mathrm{U}+$ ion ratios related to the stoichiometry of unirradiated polycystalline $\mathrm{UO}_{2}$. 